\title{
Distribution of the Excitatory Amino Acid Receptor Subunits GluR2(4) in Monkey Hippocampus and Colocalization with Subunits GluR5-7 and NMDAR1
}

\author{
S. J. Siegel,, ${ }^{1}$ W. G. Janssen, ${ }^{1}$ J. W. Tullai, ${ }^{1}$ S. W. Rogers, ${ }^{3}$ T. Moran, ${ }^{4}$ S. F. Heinemann, ${ }^{5}$ and J. H. Morrison ${ }^{1,2}$ \\ ${ }^{1}$ Fishberg Research Center for Neurobiology, ${ }^{2}$ Department of Geriatrics and Adult Development, and ${ }^{3}$ Department of \\ Microbiology, Mount Sinai School of Medicine, New York, New York 10029, ${ }^{4}$ Department of Human Genetics, \\ University of Utah, Salt Lake City, Utah 84112, and ${ }^{5}$ Molecular Neurobiology Laboratory, Salk Institute for Biological \\ Studies, La Jolla, California 92037
}

lonotropic excitatory amino acid (EAA) receptors are divided pharmacologically into three categories termed NMDA, AMPA/kainate, and high affinity kainate receptors. Each of these receptor subtypes is composed of a specific subset of subunits termed GluR1-4 (AMPA/kainate), GluR5-7, KA1-2 (high affinity kainate), and NMDAR1, 2 A-D (NMDA). Although colocalization of NMDA and non-NMDA receptors has been previously demonstrated electrophysiologically in rat, comprehensive analyses of subunit specific colocalization patterns have not been possible until the advent of appropriate antibodies. The present study investigates such immunocytochemical colocalization of several EAA receptor subunits within individual cells as well as dendritic spines in the monkey hippocampus. Double-label immunohistochemical experiments using antibodies which are specific for GluR2(4), GluR5-7, and NMDAR1 demonstrated that virtually all projection neurons in each subfield of the hippocampus contain subunits from the AMPAkainate, kainate, and NMDA receptor families. In addition, confocal microscopy has demonstrated that individual spines may contain subunits representative of multiple EAA receptor families.

Furthermore, detailed regional, cellular, and ultrastructural distribution patterns of the EAA receptor subunits GluR2 and GluR4 in monkey hippocampus are presented based on the use of a monoclonal antibody (mAb), 3A11, which was generated against the putative extracellular $\mathrm{N}$-terminal domain of GluR2. Since this antibody recognizes only GluR2 in Western blots, and GluR2 as well as GluR4 in fixed transiently transfected cells, it has been designated anti-GluR2(4). Immunocytochemical labeling with

\footnotetext{
Received July 7, 1994; revised Oct. 18, 1994; accepted Nov. 9, 1994.

We thank A. Gazzaley, P. R. Hof, G. W. Huntley, E. A. Nimchinsky, and J. C. Vickers for critical reading and helpful comments on the manuscript. Additionally, we thank R. S. Woolley for photographic assistance and R. Moosher for assistance with confocal graphics. This study was generously supported by a Charles A. Dana Foundation Research Fellowship (S.J.S.), The Charles A. Dana Foundation, National Institutes of Health Grant NS AGO6647 (J.H.M.),

The Human Frontiers Science Program and National Institutes of Health Grant NS28709 (S.F.H.).

Correspondence should be addressed to John H. Morrison, Box 1065, Fishberg Research Center for Neurobiology, Mount Sinai School of Medicine, One Gustav L. Levy Place, New York, NY 10029.

Copyright (C) 1995 Society for Neuroscience $0270-6474 / 95 / 152707-13 \$ 05.00 / 0$
}

mAb 3A11 revealed pyramidal cell somata and dendrites in each field of the hippocampus, as well as granule cells and polymorphic hilar cells in the dentate gyrus. Small cells with the morphologic characteristics of astroglia were also immunolabeled for GluR2(4) within the alveus and fimbria. Immunoreactivity at the ultrastructural level was localized to postsynaptic densities on dendritic spines and shafts and within the somatodendritic cytoplasm in all major hippocampal regions, as well as in a subset of dentate granule cell axons within the mossy fiber projection.

[Key words: glutamate, AMPA, kainate, NMDA, CA3, primate, cortex]

Individual excitatory inputs to a given neuron are likely to differ in their postsynaptic complement of EAA receptor subunits. Furthermore, the precise FAA receptor subunit composition is likely to be a crucial determinant of the response properties of a given neuron or circuit. However, in addition to describing the cellular complement of EAA receptor subunits within a given cell type, it will be necessary to localize specific groups of EAA receptor subunits to specific sets of synapses at the ultrastructural level and eventually to relate these synaptic distribution patterns to identified afferents. Toward these ends, several immunocytochemical studies have recently been published on the localization of NMDA and non-NMDA EAA receptor subunit proteins in the mammalian CNS (Petralia and Wenthold, 1992; Good et al., 1993; Huntley et al., 1993, 1994; Martin et al., 1993; Vickers et al., 1993; Siegel et al., 1994). Studies of the hippocampus have demonstrated NMDA and non-NMDA receptor subunit immunoreactivity at a subset of postsynaptic densities as well as within the somatodendritic cytoplasm (Petralia and Wenthold, 1992; Good et al., 1993; Martin et al., 1993; Siegel et al., 1994). Additionally, immunoreactivity for NMDAR1 has been reported in dentate granule cell axons within the mossy fiber projection to CA3 (Siegel et al., 1994). Although the regional distribution of the AMPA/kainate subunits GluR2/3 has been described in rat brain (Petralia and Wenthold, 1992; Martin et al., 1993), the present report focuses with greater detail on the cellular and ultrastructural patterns of GluR2(4) subunit immunoreactivity and examines patterns of colocalization for AMPA/kainate, kainate, and NMDA receptor subunits within select cell types and/ or laminae in the monkey hippocampus. While such colocalization patterns for the various EAA receptor classes have been 


\begin{tabular}{|c|c|c|c|}
\hline Antibody & Source & Amino acid sequence/epitope & Reference \\
\hline $\begin{array}{l}3 \mathrm{~A} 11 \\
\text { monoclonal }\end{array}$ & $\begin{array}{l}\text { J. H. Morrison, T. } \\
\text { Moran, S. H. } \\
\text { Heinemann, S. W. } \\
\text { Rogers }\end{array}$ & $\begin{array}{l}\text { GluR2 aa } 170-430 \\
\text { GluR2(4), putative N-terminal region }\end{array}$ & $\begin{array}{l}\text { Puchalski et al } \\
\text { (1994), present } \\
\text { study }\end{array}$ \\
\hline $\begin{array}{l}54.1 \\
\text { monoclonal }\end{array}$ & $\begin{array}{l}\text { N. Brose, S. H. } \\
\text { Heinemann, R. Jahn, } \\
\text { J. H. Morrison }\end{array}$ & $\begin{array}{l}\text { NMDAR } 1 \text { aa } 660-811 \\
\text { NMDAR } 1 \text {, pulative inlracellular loop } \\
\text { between transmembrane domains } 3 \\
\text { and } 4\end{array}$ & Siegel et al. (1994) \\
\hline $\begin{array}{l}\text { 4F5 } \\
\text { monoclonal }\end{array}$ & $\begin{array}{l}\text { J. H. Morrison, T. } \\
\text { Moran, S. H. } \\
\text { Heinemann, S. W. } \\
\text { Rogers }\end{array}$ & $\begin{array}{l}\text { GluR } 5 \text { aa } 233-518 \\
\text { GluR } 5-7 \text {, putative } N \text {-terminal region }\end{array}$ & Huntley et al. (1993) \\
\hline
\end{tabular}

demonstrated physiologically at select synapses in hippocampus (Bekkers and Stevens, 1989) and have been inferred from previous single-label immunohistochemical, in situ hybridization and ligand binding studies, the present study provides the first direct anatomic double-label analyses for the existence of multiple classes of EAA receptors within individual neurons and spines in monkey hippocampus.

\section{Materials and Methods}

\section{Generation of $\mathrm{mA} b 3 \mathrm{~A} 11$}

The monoclonal antibody $3 \mathrm{~A} 11$ is a mouse $\gamma$ type immunoglobulin (IgG) of the subclass IgG2a, which was generated according to procedures described previously (Huntley et al., 1993) against a fusion protein encoding the putative extracellular N-terminal domain of GluR2 (amino acids 170-430) (Table 1).

Fusion protein production. The trpE bacterial overexpression system (Dieckmann and Tzagoloff, 1985) was used to obtain GluR2 antigen for antibody production as previously described (Rogers et al., 1991). Briefly, a Bg1II-Sma1 fragment of the GluR2 cDNA containing nucleotides encoding amino acids 170-430, (Boulter et al., 1990) was shuttle cloned into the BamH1-Hind2 sites of vector pUC18. This fragment was then removed using Sma1 and Hind3 for subcloning into the pATH2 expression vector at the same restriction enzyme sites. Additional proteins were prepared for use in radioimmunoassay (RIA) analysis and immunocytochemical blocking experiments. Protein from GluRI (long construct), GluR3, and GluR5 were the same as previously described (Rogers et al., 1991). Antigen production, enrichment, and purification by SDS-PAGE fractionation was done as previously described (Rogers et al., 1991).

Soluble fusion proteins were prepared by dissolving enriched antigen into freshly prepared $8 \mathrm{M}$ urea $(10 \mathrm{ml}$ per gram of protein) at room temperature for $1 \mathrm{hr}$. The solution was clarified by centrifugation and the supernatant diluted 1:10 by the slow addition of a solution consisting of $50 \mathrm{~mm} \mathrm{KCl}$ and $50 \mathrm{~mm} \mathrm{NaCl}(\mathrm{pH} 10.5)$. After an additional hour of stirring at room temperature, the solution was brought to $\mathrm{pH} 8$ with $1 \mathrm{~N} \mathrm{HCl}$ and repeatedly dialyzed against $10 \mathrm{~mm} \mathrm{NaCl}$ in $10 \mathrm{~mm}$ sodium phosphate buffer $\left(\mathrm{pH} \mathrm{7.2)}\right.$ at $40^{\circ} \mathrm{C}$. The concentration of soluble proteins was then measured by the method of Lowry (Lowry et al., 1951).

Monoclonal antibody production. Monoclonal antibodies were produced by immunizing $6-8$ week old $B A L B / c$ mice with polyacrylamide gel strips emulsified in Complete Freund's Adjuvant in the foot pads and intraperitoneally. The animals were boosted after 3 weeks with gel strips emulsified in Incomplete Freund's Adjuvant. Boosts were repeated two additional times at monthly intervals. Serum antibody titers were checked by RIA (see below) and the animal with the highest titer was selected for fusion. Ten million SP2/0 BALB/c myeloma cells were mixed with $100 \times 10^{6}$ spleen cells and fused by the dropwise addition of PEG 4000 using a standard technique. Colonies were visible $12 \mathrm{~d}$ later and supernatants were removed and analyzed for the presence of specific antibodies by RIA.

\section{Characterization of $m A b 3 A 11$}

Radioimmunoassay. Radioimmunoassay was performed by coating 96 well flexible plates (Falcon Microtest III) with $5 \mu \mathrm{g} / \mathrm{ml}$ of fusion proteins encoding GluR1, GluR2, GluR3, the $\beta 4$ subunit of the nicotinic acetylcholine receptor $(\beta 4)$, or $\operatorname{trp} E$ alone as a control overnight at $4^{\circ} \mathrm{C}$. The plates were then blocked with $1 \%$ bovine serum albumin (BSA) in $0.1 \mathrm{M}$ phosphate-buffered saline (PBS) for $30 \mathrm{~min}$ at room temperature after which undiluted hybridoma supernatants $(50 \mu l)$ were added to triplicate wells. Following a $90 \mathrm{~min}$ incubation at room temperature, 50 $\mu \mathrm{l}\left(50,000\right.$ counts per minute) of ${ }^{125}$ I-labeled goat anti-mouse IgG (heavy chain specific) was added to each well. After an additional 90 min incubation at room temperature, plates were washed, cut up and placed in a gamma counter.

Cell transfection and immunocytochemistry. Immunocytochemistry was performed on human embryonic kidney 293 (HEK-293) cells which were transiently transfected with either GluR1, GluR2, GluR3, or GluR4, respectively, to evaluate subunit specificity of mAb 3A11. Full length cDNAs encoding the above subunits were subcloned into cytomegalovirus driven expression vectors. DNA plasmids were isolated using the Qiagen system (Qiagen, Chatsville, CA). HEK-293 cells were then transfected with $8 \mu \mathrm{g}$ of plasmid DNA per $100 \mathrm{~mm}$ dish at $70 \%$ confluence using the Lipofectamine liposomal method (Lipofectaminc, GIBCO/Bethesda Research Labs, Gaithersburg, MD). At $24 \mathrm{hr}$, cells were titurated from dishes onto four well chamber slides (Nunc, $\mathrm{Na}$ perville, IL) and grown for $24 \mathrm{hr}$ in DMEM with $10 \%$ fetal calf serum in a humidified atmosphere containing $5 \% \mathrm{CO}_{2}$ at $37^{\circ} \mathrm{C}$. Cells were fixed at $48 \mathrm{hr}$ for 15-30 min at room temperature by addition of $4 \%$ freshly prepared paraformaldehyde (Electron Microscopy Sciences, Fort Washington, PA) in $0.2 \mathrm{M}$ cacodylate buffer. The fixative was removed and cells were blocked with $3 \%$ normal horse serum, (Vector Laboratories, Burlingame, CA) and processed for immunocytochemistry by the avidin-biotin-peroxidase method using Vectastain $\mathrm{ABC}$ kit (Vector Laboratories, Burlingame, CA) followed by treatment with $0.05 \%$ diaminobenzidine (DAB) with $0.003 \%$ hydrogen peroxide.

Immunohistochemical blocking of $\mathrm{mAb} 3 \mathrm{All}$ with fusion proteins. Preadsorption of the anti-GluR2(4) monoclonal antibody 3A11 was performed with fusion proteins encoding the N-terminal portion of GluR2 as well as GluR1, GluR3, and GluR5, the $\beta 4$ subunit of the nicotinic acetylcholine receptor and trp $E$ alone. Primary antibody was incubated overnight at $4^{\circ} \mathrm{C}$ with each of the fusion proteins listed above. Fusion protein encoding the homologous region of GluR4 was not available to be tested. Following centrifugation, supernatant was extracted and incubated with fresh fusion proteins for one hour. Preadsorbed primary antibody was then cleared by centrifugation and was used for immunohistochemistry as described below.

\section{Characterization of anti-GluR5-7 and NMDARl mAbs}

The $\mathrm{mAb} 4 \mathrm{F5}$ is a $\mu$ type immunoglobulin (IgM) which was raised against a fusion protein corresponding to the putative extracellular N-terminal domain of GluR5 and recognizes GluR5-7 (Table 1) (Huntley et al., 1993). This antibody has been previously characterized bio- 
Radioimmunoassay

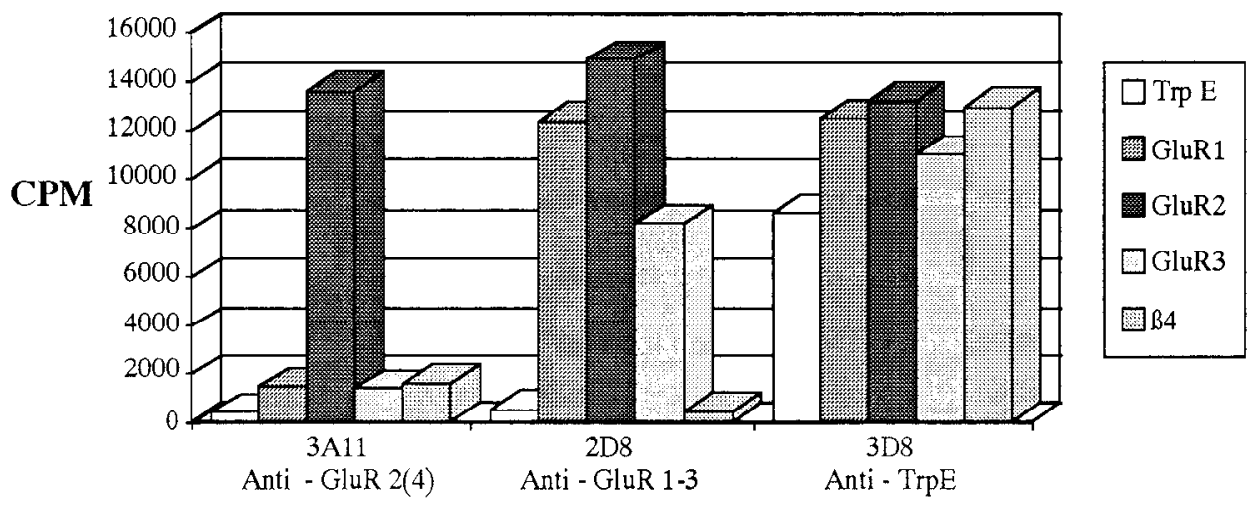

Monoclonal Antibodies
Figure 1. Radioimmunoassay results for the monoclonal antibody $3 \mathrm{~A} 11$. Individual wells were coated with $5 \mu \mathrm{g} /$ $\mathrm{ml}$ of fusion proteins encoding GluR1, GluR2, GluR3, $\beta 4$, or $\operatorname{trp} E$ alone. Following incubation with primary antibody, wells were labeled with ${ }^{125} \mathrm{I}-\mathrm{la}$ beled goat anti mouse $\mathrm{IgG}$, washed and counted in a gamma counter. Specific binding of mAb $3 \mathrm{All}$ I was only found to GluR2. Two additional monoclonal antibodies were used as controls to demonstrate the presence of the additional fusion proteins. Monoclonal antibody 2D8 recognizes the EAA receptor subunits GluR $1-3$, while $\mathrm{mAb}$ 3D8 recognizes $\operatorname{trpE}$. chemically with immunoblots, and immunohistochemically in transfected cells, as well as primate neocortex and hippocampus (Good et al., 1993; Huntley et al., 1993; Vickers et al., 1993). The mAb 54.1 is an IgG which was generated according to standard procedures (Jahn et al., 1985; Köhler and Milstcin, 1975), using a fusion protein encoding glutathione-S-transferase (GST) in frame with NMDAR 1 residues $660-$ 811 , representing the putative intracellular loop between transmembrane regions III and IV; residue numbers as in Moriyoshi et al. (Moriyoshi et al., 1991) and recognizes NMDARl (Siegel et al., 1994). This antibody has been previously characterized biochemically with immunoblots as well as immunohistochemically in transiently transfected cells and primate hippocampus and neocortex (Table 1) (Huntley et al., 1994; Siegel et al., 1994)

\section{Animals}

The hippocampi from the brains of 18 macaque monkeys were examined in this study including 3 monkeys at 3 months of age, 3 monkeys at 6 months of age, and 12 adult monkeys. All protocols were conducted within NIH guidelines for animal research and were approved by the Institutional Animal Care and Use Committee (IACUC).

\section{Tissue preparation}

Animals were deeply anesthetized with ketamine hydrochloride (15-25 $\mathrm{mg} / \mathrm{kg}$ i.m.) and pentobarbital sodium ( $10-20 \mathrm{mg} / \mathrm{kg}$ i.v.) and perfused transcardially with cold $1 \%$ paraformaldehyde in PBS for approximately 1 min and then with cold $4 \%$ paraformaldehyde in PBS for an additional $8-9 \mathrm{~min}$. The brains were removed, cut into approximately $5 \mathrm{~mm}$ thick blocks and placed in cold 4\% paraformaldehyde in PBS for $6 \mathrm{hr}$. Brains from six of the adult animals were prepared with fixation that included $0.25-1 \%$ glutaraldehyde as well as $4 \%$ paraformaldehyde. Blocks were then placed directly into PBS and sectioned in a plane perpendicular to the superior temporal sulcus at 50-80 $\mu \mathrm{m}$ using a vibratome (Ted Pella Inc., Irvine, CA). Tissue sections were then processed for either single or double labeling immunohistochemistry using the subunit specific EAA receptor antibodies described below. All figures are generated with tissue sections from adult monkey brains. Figures 3, 4, 6, and 7 were generated with tissue which was fixed with $4 \%$ paraformaldehyde, while Figures 5 and 8 contain tissue which was prepared with fixation that included $0.25-1 \%$ glutaraldehyde as well as $4 \%$ paraformaldehyde.

\section{Immunocytochemistry}

Tissue sections for single label immunocytochemistry were incubated with anti-GluR2(4) mAb $3 \mathrm{~A} 11$ for $48 \mathrm{hr}$, followed by the avidin-biotinperoxidase method using Vectastain $\mathrm{ABC}$ kit (Vector Laboratories, Burlingame, $\mathrm{CA}$ ), and treatment with $0.05 \% \mathrm{DAB}$ with $0.003 \%$ hydrogen peroxide. Additional tissue sections which were labeled with the antiGluR2(4) mAb 3A11 were further processed for electron microscopy. Following $\mathrm{DAB}$, these sections were treated with $0.5 \%$ osmium tetroxide in $7 \%$ sucrose, dehydrated, embedded in resin (Araldite, Electron Microscopy Services, Fort Washington, PA), and sectioned at $3 \mu \mathrm{m}$ on an ultramicrotome (Ultracut E, Reichert-Jung, Germany). These sections were then reembedded in resin and thin sectioned for electron microscopy.
Double-label immunohistochemistry for GluR5-7 with GluR2(4) as well as GluR5-7 with NMDAR1 was performed by incubating tissue sections with mAbs 4F5 (anti-GluR5-7) and either 54.1 (antiNMDAR1) or $3 A 11$ [anti-GluR2(4)] for $24-48$ hr. Following three washes in PBS, sections were incubated for $2 \mathrm{hr}$ in ГITC-conjugated goat anti-mouse IgM $\mu$ chain specific antisera (Vector Laboratories, Burlingame, CA) and biotinylated horse anti-mouse IgG $\gamma$ chain specific antisera (Vector Laboratories, Burlingame, CA). Following three additional washes in PBS, sections were incubated with Texas red-conjugated avidin (Vector Laboratories, Burlingame, CA). As an immunohistochemical control for this procedure, additional sections were incubated with mAbs 54.1 or $3 \mathrm{~A} 11$ followed by FITC-conjugated goat anti-mouse $\operatorname{IgM} \mu$ chain specific antisera or mAb 4F5 followed by biotinylated horse anti-mouse IgG $\gamma$ chain specific antisera and Texas red-conjugated avidin. These experiments were designed to determine whether or not the secondary antibodies had sufficient specificity to differentiate the IgM and IgG primary antibodies, thus ruling out the visualization of the appropriate primary antibody by an inappropriate secondary antibody (see Гig. 3). As both mAbs $3 \mathrm{~A} 11$ and 54.1 are IgG type antibodies, this combination could not be directly examined with these immunofluorescent procedures.

\section{Analysis}

Both DAB- and Texas red/FITC-labeled tissue sections were examined on an Axiophot microscope (Zeiss, Germany) for conventional brightfield and fluorescence light microscopic analyses. Double labeled fluorescence material was also analyzed on a confocal laser scanning microscope model LSM-410 (Zeiss, Germany). An argon/krypton laser with excitation peaks at $488 \mathrm{~nm}$ (for FITC-labeled profiles) and $568 \mathrm{~nm}$ (for Texas red-labeled protiles) was used in conjunction with an FT560 beam splitter and two separate detectors equipped with an LP-590 and a BP-510-525 filter, respectively. Ultrastructural analyses were performed on a Hitachi 7000 electron microscope (Hitachi, Japan).

\section{Results}

\section{Specificity of mAb $3 A 11$ immunoreactivity}

Radioimmunoassay. The mAb 3A11 was tested by RIA utilizing fusion proteins encoding homologous regions of GluR1-3, and two control peptides encoding the $\beta 4$ subunit of the nicotinic $A C h$ receptor or $\operatorname{trpE}$, respectively (Fig. 1). This resulted in binding of mAb $3 \mathrm{~A} 11$ to the GluR2-specific fusion protein, but not to fusion proteins encoding GluR1, GluR3, or the two control peptides. Fusion protein encoding the homologous region of GluR4 was not available to be tested by either RIA or in immunohistochemical blocking experiments.

Immunocytochemistry on transiently transfected HEK-293 cells. Immunocytochemistry using mAb $3 \mathrm{All}$ specifically labeled paraformaldehyde-fixed GluR2 as well as GluR4-transfected HEK-293 cells, but did not label wild-type HEK-293 cells or those transfected with GluR1 or GluR3 (Fig. 2). 

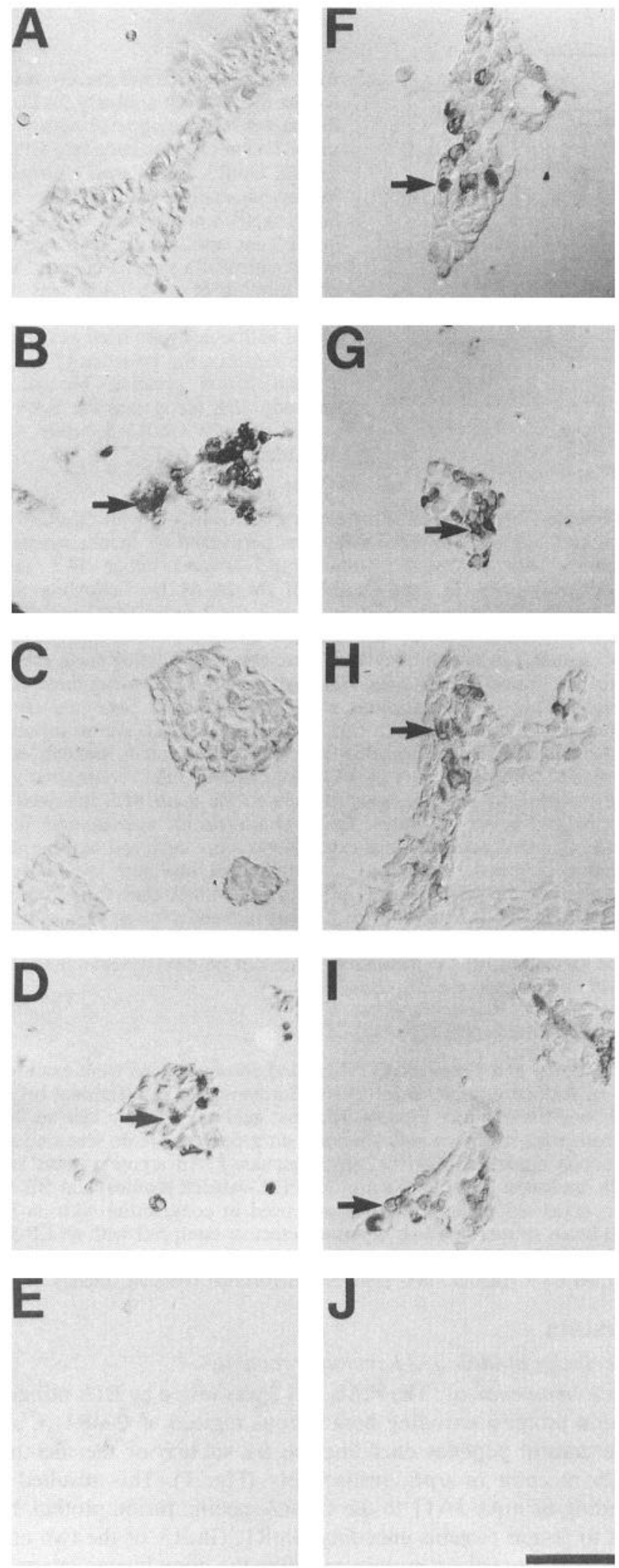

Figure 2. Immunocytochemical labeling of HEK-293 cells which have been transiently transfected with GluR1 $(A, F)$, GluR2 $(B, G)$, GluR3 $(C, H)$, or GluR4 $(D, I)$ as well as wild-type cells $(E, J) . A-E$ are labeled with mAb $3 \mathrm{~A} 11 . F-J$ are labeled with $\mathrm{mAb} 2 \mathrm{D} 8$, which recognizes GluR1-3 in RIA, as a control. Note that mAb 3A11 labels cells transfected with GluR2 and GluR4, but not wild-type cells or those transfected with GluR1 or GluR3, while mAb 2D8 labels cells transfected with GluR1-4, but not wild-type cells. Arrows indicate examples of immunolabeled cells. Scale bar, $100 \mu \mathrm{m}$.
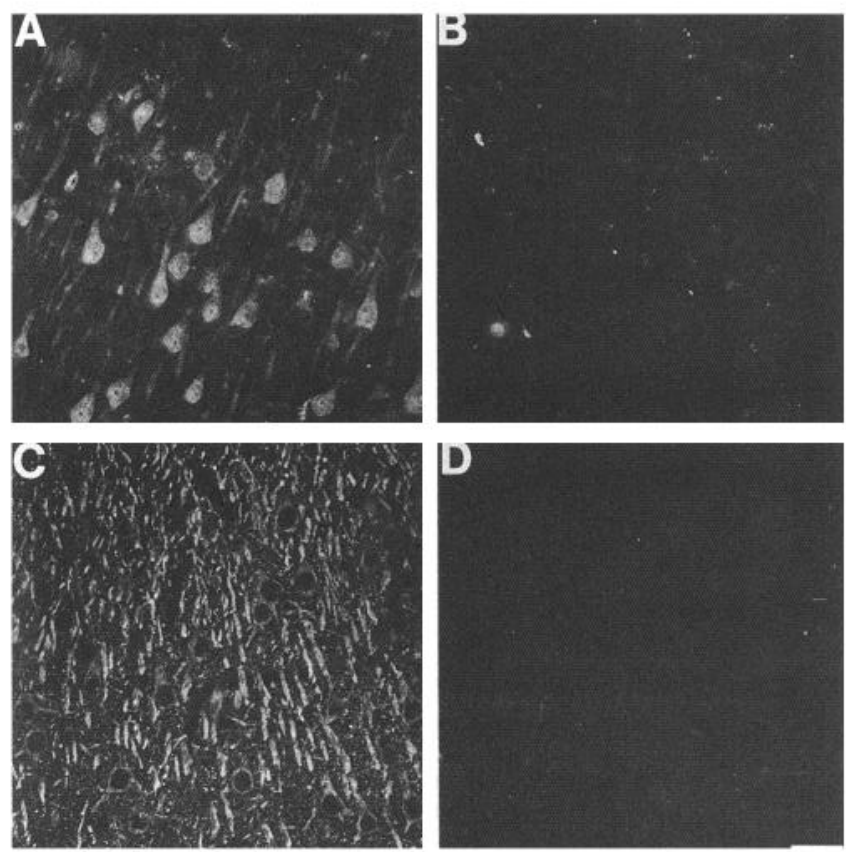

Figure 3. Control for cross-reactivity of secondary antibodies used in double-label immunocytochemistry. $A$ and $B$, CAl pyramidal cells labeled with IgG type mAb 3A11 followed by biotinylated horse antimouse IgG g chain specific antisera and Texas red-conjugated avidin (A) or FITC-conjugated goat anti-mouse IgM $\mu$ chain specific antisera (B). $C$ and $D, C A 1$ pyramidal cells labeled with IgM type mAb 4F5 followed by FITC-conjugated goat anti-mouse IgM $\mu$ chain specific antisera $(C)$ or biotinylated horse anti-mouse $\mathrm{IgG} \gamma$ chain specific antisera and Texas red-conjugated avidin $(D)$. Note that neither primary antibody was labeled by the inappropriate secondary antibody. Bright patches in $B$ are due to lipofuscin autoflourescence. Scale bar, $50 \mu \mathrm{m}$.

Immunocytochemical controls on tissue sections. The specificity of mAb $3 \mathrm{~A} 11$ was also verified in the present report immunohistochemically through blocking experiments. Specific labeling in monkey hippocampus was abolished following preadsorption with a fusion protein containing a $\mathrm{N}$-terminal portion of GluR2, but was unaffected by incubation with fusion proteins encoding homologous portions of GluR1, GluR3, GluR5, the $\beta 4$ subunit of the nicotinic ACh receptor or $\operatorname{trpE}$ alone. As an immunohistochemical control for specificity of the secondary antibodies in the double labeling procedures, sections were incubated with mAbs 54.1 or $3 \mathrm{All}$ followed by FITCconjugated goat anti-mouse $\operatorname{IgM} \mu$ chain specific antisera or $\mathrm{mAb} 4 \mathrm{~F} 5$ followed by biotinylated horse anti-mouse IgG $\gamma$ chain specific antisera and Texas red-conjugated avidin. Neither of these conditions resulted in the visualization of the appropriate primary antibody by an inappropriate secondary antibody (Fig. 3).

\section{Immunocytochemistry on monkey hippocampus}

Patterns of immunoreactivity for GluR5-7 and NMDARI. Although age did not result in differences in the overall patterns of immunoreactivity, all figures demonstrate examples from adult animals. The mAb 3A11 labeled neuronal elements within each of the major hippocampal fields (Fig. 4). Dentate gyrus granule cell somata and proximal dendrites within the granule cell layer, as well as dendrites throughout the molecular layer, including extremely fine distal dendritic processes which terminated at the hippocampal fissure were intensely labeled (Fig. 


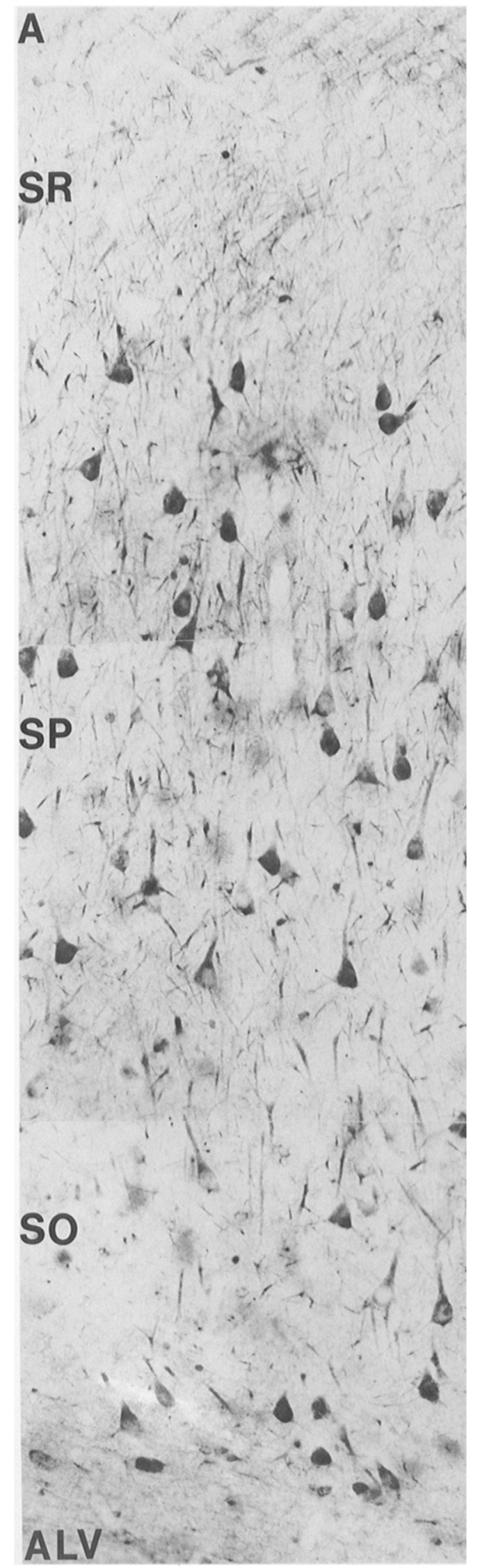

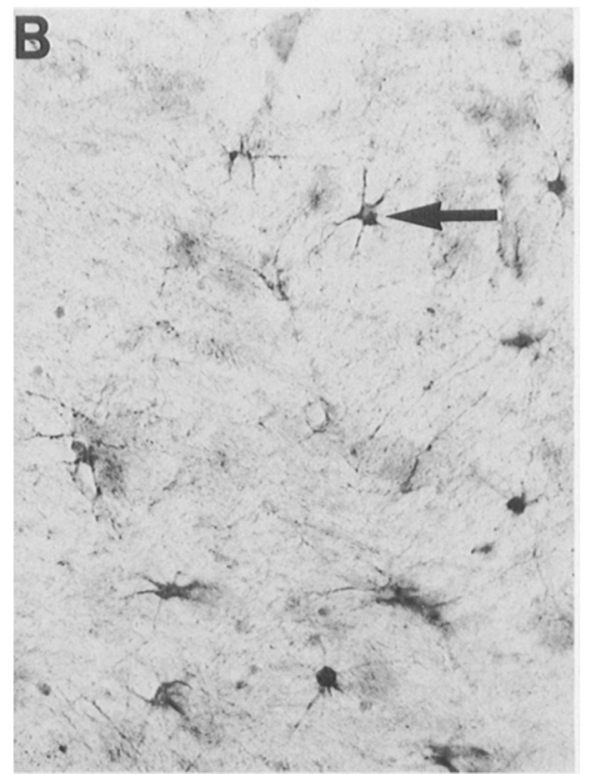
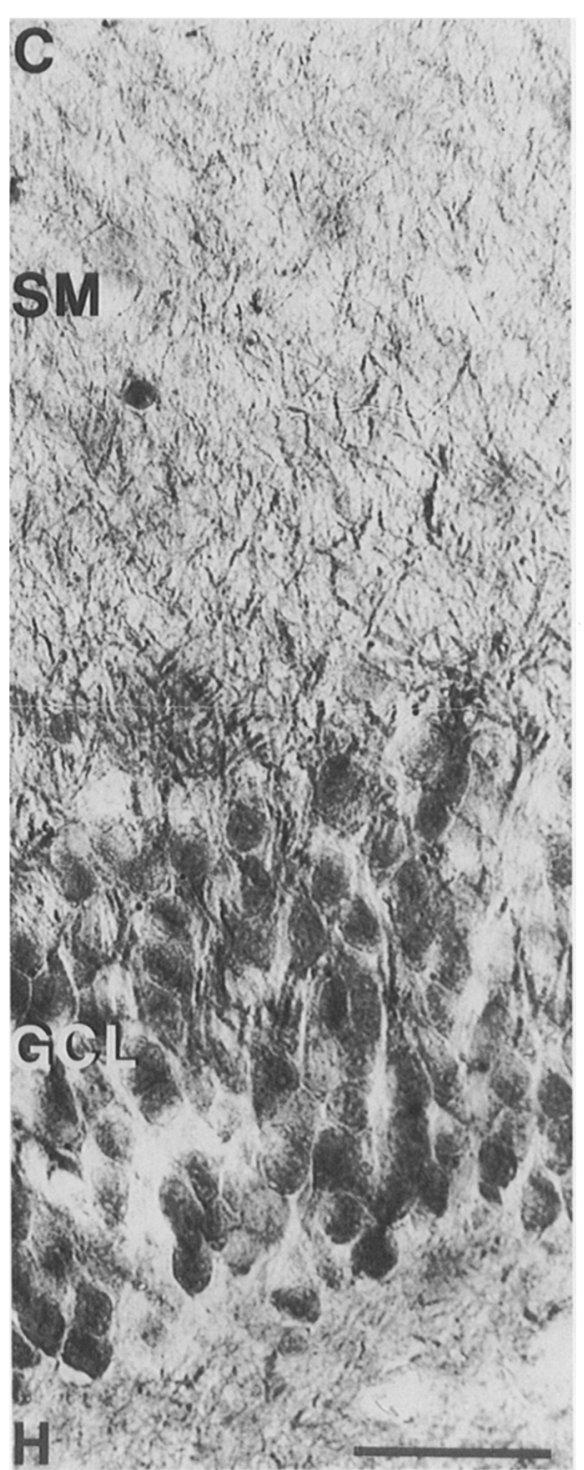

Figure 4. Light microscopic distribution of GluR2(4)-immunolabeled cells in adult monkey CA1 $(A)$, fimbria $(B)$, and dentate gyrus $(C) . A, C A 1$ pyramidal cell somata in stratum pyramidale and dendrites in all layers are well labeled. $B$, Small immunolabeled cells with the appearance of fibrous astrocytes (arrow) were visible within the fimbria. $C$, Dentate granule cell somata and dendrites are clearly labeled within the granule cell layer and throughout the molecular layer. $A L V$, alveus; $G C L$, granule cell layer; $H$, hilus; $S M$, stratum moleculare; $S O$, stratum oriens; $S P$, stratum pyramidale; $S R$, stratum radiatum. Scale bar: $A, 100 \mu \mathrm{m} ; B, 65$ $\mu \mathrm{m} ; C, 40 \mu \mathrm{m}$. 
$4 C$ ). The intensity of immunoreactivity in the inner and outer portions of the dentate molecular layer was equivalent. The perikarya and dendrites of hilar neurons were intensely GluR2(4) immunoreactive [GluR2(4)-ir]. Cell somata in continuity with proximal dendrites were well labeled throughout their cytoplasm, as were extremely fine, presumably distal dendritic processes within the neuropil. Both the somata and basal dendrites of CA3 pyramidal cells in the stratum pyramidale and stratum oriens displayed immunoreactivity for GluR2(4), as did the apical dendrites extending through the stratum lucidum, stratum radiatum, and stratum moleculare (Fig. $5 F$ ). Within the stratum lucidum of CA3, neuropil containing axons and terminals of the mossy fiber projection between bundles of pyramidal cell apical dendrites displayed a diffuse, faint pattern of immunoreactivity (Fig. $5 F$, asterisk). Such a pattern of immunoreactivity is comparable to that seen with antibodies to other proteins which label the mossy fiber projection (Seress et al., 1991). In both CA1 (Fig. 4A) and the subiculum, pyramidal cell somata, as well as large caliber apical and basal dendrites, were intensely GluR2(4)-ir. Strata radiatum and moleculare were characterized by increasingly fine caliber immunoreactive processes terminating at the hippocampal fissure (Fig. 4A). Throughout Ammon's horn, the neuropil of stratum pyramidale had a reticular appearance, presumably representing immunolabeling of extremely fine caliber distal dendritic processes. Nonpyramidal fusiform cells in stratum oriens were lightly labeled for GluR2(4) with immunoreactivity visible in their somata and proximal dendrites. Small cells with the morphologic characteristics of fibrous astrocytes in the alveus and fimbria were also labeled for GluR2(4) throughout Ammon's horn and the subiculum (Fig. 4B).

Patterns of immunoreactivity for GluR5 7 and NMDARl. The patterns of immunoreactivity for GluR5-7 (Good et al., 1993) and NMDAR1 (Siegel et al., 1994) within the monkey hippocampal formation have been described previously and therefore will be described here only briefly. Dentate granule cells were labeled in their somatodendritic compartment for both GluR5-7 (Figs. 6, 7) and NMDAR1 (Fig. 7) with a pattern similar to that described for GluR2(4). IIilar polymorphic cells were intensely immunoreactive with antibodies directed against both categories of subunits, as were pyramidal cells in all subdivisions of Ammon's horn and the subiculum. Similarly, nonpyramidal cells in the stratum oriens and neuroglial cells in the alveus and fimbria were also labeled for GluR5-7 as well as NMDAR1.

Colocalization of GluR2(4) and GluR5-7. Although subtle differences were evident between the patterns of immunoreactivity for mAbs 3A11 [anti-GluR2(4)] and 4F5 (anti-GluR5-7), double-label immunohistochemistry resulted in a pattern of colocalization throughout the hippocampus in which virtually all cells which were labeled with one $\mathrm{mAb}$ were also labeled with the other (Figs. 5, 7). Pyramidal cells in both CA1 (Fig. 5A,B) and the subiculum were immunoreactive for both antibodies in virtually every somatic and dendritic segment examined, as were polymorphic hilar neurons. Dentate granule cells displayed colocalization of GluR2(4) and GluR5-7 within their somata and throughout the entire extent of their dendrites (Fig. $5 C, D$ ). Sim- ilarly, CA3 pyramidal cell hodies as well as hoth apical and basal dendrites were labeled in virtually all cases with both antibodies (Fig. 5E,F). Additionally, mossy fibers within the neuropil of stratum lucidum were lightly labeled for GluR2(4) and to a lesser extent for GluR5-7 (asterisks, Fig. 5E,F).

Colocalization of GluR5-7 and NMDAR1. Immunohistochemistry utilizing mAbs directed against GluR5-7 (mAb 4F5) and NMDAR1 (mAb 54.1) resulted in a cellular pattern of colocalization which was similar to that seen for GluR5-7 and GluR2(4). Virtually all somatic and dendritic profiles within each of the subfields were labeled with both of these antibodies, resulting in immunoreactive patterns which were very similar on both conventional (Fig. 6) and confocal laser scanning (Fig. 7) images. Dentate granule cells displayed colocalization of these receptor subtypes within their somata and throughout their dendritic arbor (Fig. 6A,B). Similarly, pyramidal cells in CA1 (Fig. $6 C, D)$, the subiculum and the hilus were double labeled for GluR5-7 and NMDAR1 in virtually every somatic and dendritic segment examined. CA3 pyramidal cell bodies and dendrites also displayed colocalization of GluR5-7 and NMDAR1 (Fig. $6 E, F)$. Mossy fibers within the neuropil of stratum lucidum were labeled for NMDAR1 and to a lesser extent for GluR5-7 (asterisks, Fig. $6 E, F$ ). As described above, the $\mu$ - and $\gamma$-chain specific secondary antibodies used in these double-label immunohistochemical procedures did not cross react with the inappropriate primary antibody (Fig. 3), suggesting that such a high degree of colocalization between each of the combinations tested reflects the highly overlapping distribution of AMPA, kainate, and NMDA receptor subunit immunoreactivity within the monkey hippocampus. Finally, analysis of double-labeled material examined with a confocal laser scanning microscope indicated that the high affinity kainate receptor subunits GluR57 could be colocalized within individual dendritic spines with both the AMPA/kainate receptor subunits GluR2(4), as well as the NMDA receptor subunit NMDAR1 (Fig. 7).

Ultrastructural localization of GluR2(4). Immunoreactivity for GluR2(4) at the ultrastructural level was localized to asymmetric postsynaptic densities, as well as diffusely within somatodendritic cytoplasm (Fig. 8). Postsynaptic densities were considered to he specifically labeled when the postsynaptic specialization had a thickened, dark appearance and the underlying dendritic cytoplasm contained flocculent opaque material, corresponding to DAB-peroxidase deposits. GluR2(4)-ir postsynaptic densities in the dentate molecular layer were present on profiles consistent with both dendritic spines (Fig. $8 C$ ) and shafts. Similarly, such labeled postsynaptic densities were found on both spines and shafts within strata radiatum and moleculare of both CA1 (Fig. 8A,B) and CA3. Within the stratum lucidum of CA3, labeled postsynaptic densities were seen on specialized dendritic spines called thorny excrescences embedded within mossy fiber terminals, as well as asymmetric synapses on dendritic shafts (Fig. 8F). Unlabeled asymmetric postsynaptic densities on spines and shafts were apparent throughout all regions of the hippocampus in close proximity to labeled profiles. For example, multiple thorny excrescences within a single mossy

\footnotetext{
Figure 5. Pairs of photomicrographs showing double-label immunohistochemistry for FITC-labeled GluR5-7 $(A, C, E)$ and Texas red-labeled GluR2(4) $(B, D, F)$ in adult monkey hippocampus. Virtually all cells which label with either antibody also colocalized the other. $A$ and $B$, CA1 pyramidal cells; $C$ and $D$, dentate granule cells; $E$ and $F$, CA3 pyramidal cells. Notice the presence of immunoreactivity for GluR5-7 $(E)$ as well as GluR2 (4) $(F)$ between dendritic shafts in stratum lucidum. Arrows, Examples of double labeled cells; asterisks, examples of diffuse neuropil labeling within the zone of mossy fiber axon termination in stratum lucidum. Scale bars: $A, B, E$, and $F, 100 \mu \mathrm{m} ; C$ and $D, 50 \mu \mathrm{m}$.
} 


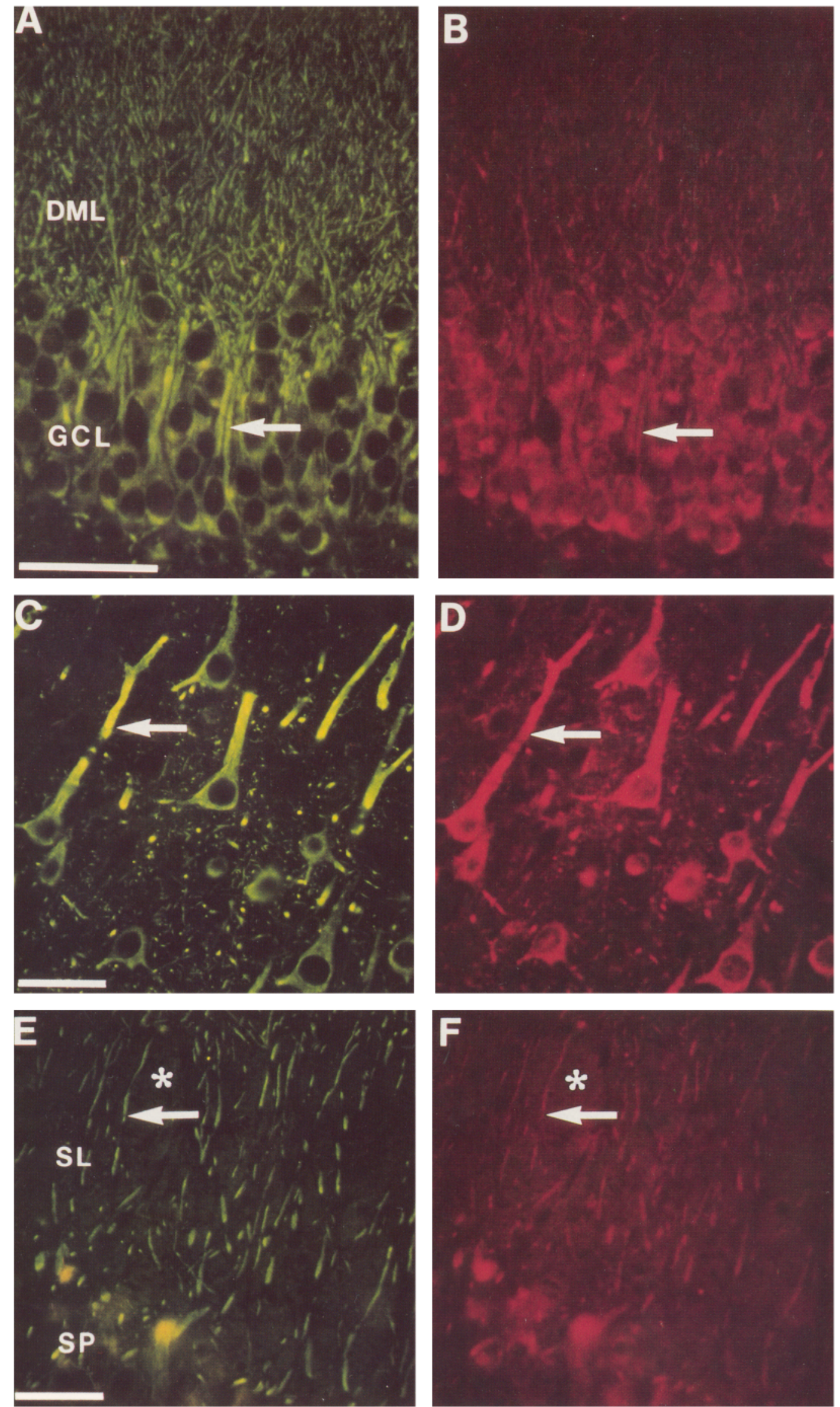

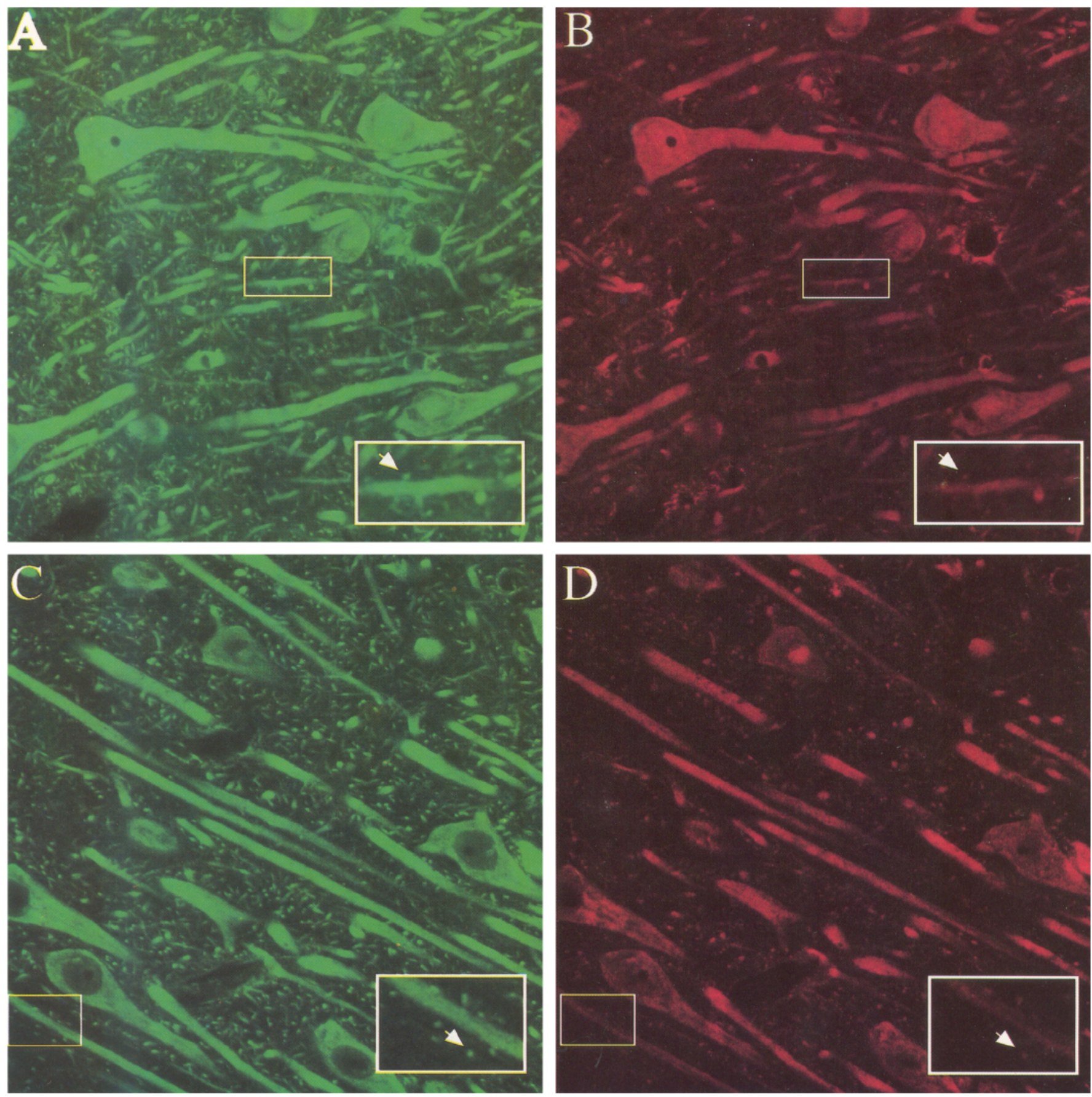

Figure 7. Pairs of pseudo-colored confocal images of double-labeled CA1 pyramidal cells from an adult monkey for FITC-labeled GluR5-7 (A, $C$ ) and Texas red-labeled GluR2(4) (B) or NMDAR1 (D). Insets (large boxes) show electronic enlargements of regions in small boxes containing double-labeled spines (arrows).

$\leftarrow$

Figure 6. Pairs of photomicrographs showing double-label immunohistochemistry for FITC-labeled GluR5-7 $(A, C, E)$ and Texas red-labeled NMDAR1 $(B, D, F)$ in adult monkey hippocampus. Virtually all cells which label with either antibody also colocalized the other. $A$ and $B$, Dentate granule cells; $C$ and $D, C A 1$ pyramidal cells; $E$ and $F, C A 3$ stratum lucidum. As in Figure 5, notice the presence of immunoreactivity for GluR5$7(E)$ as well as NMDAR1 $(F)$ between dendritic shafts in stratum lucidum. This faint immunoreactivity within the neuropil of stratum lucidum is more easily appreciated when visualized for NMDAR1 using the DAB-peroxidase technique; see Siegel et al., 1994. Arrows, Examples of double labeled cells; asterisks, examples of diffuse neuropil labeling within the zone of mossy fiber axon termination in stratum lucidum. Scale bars, $50 \mu \mathrm{m}$. 

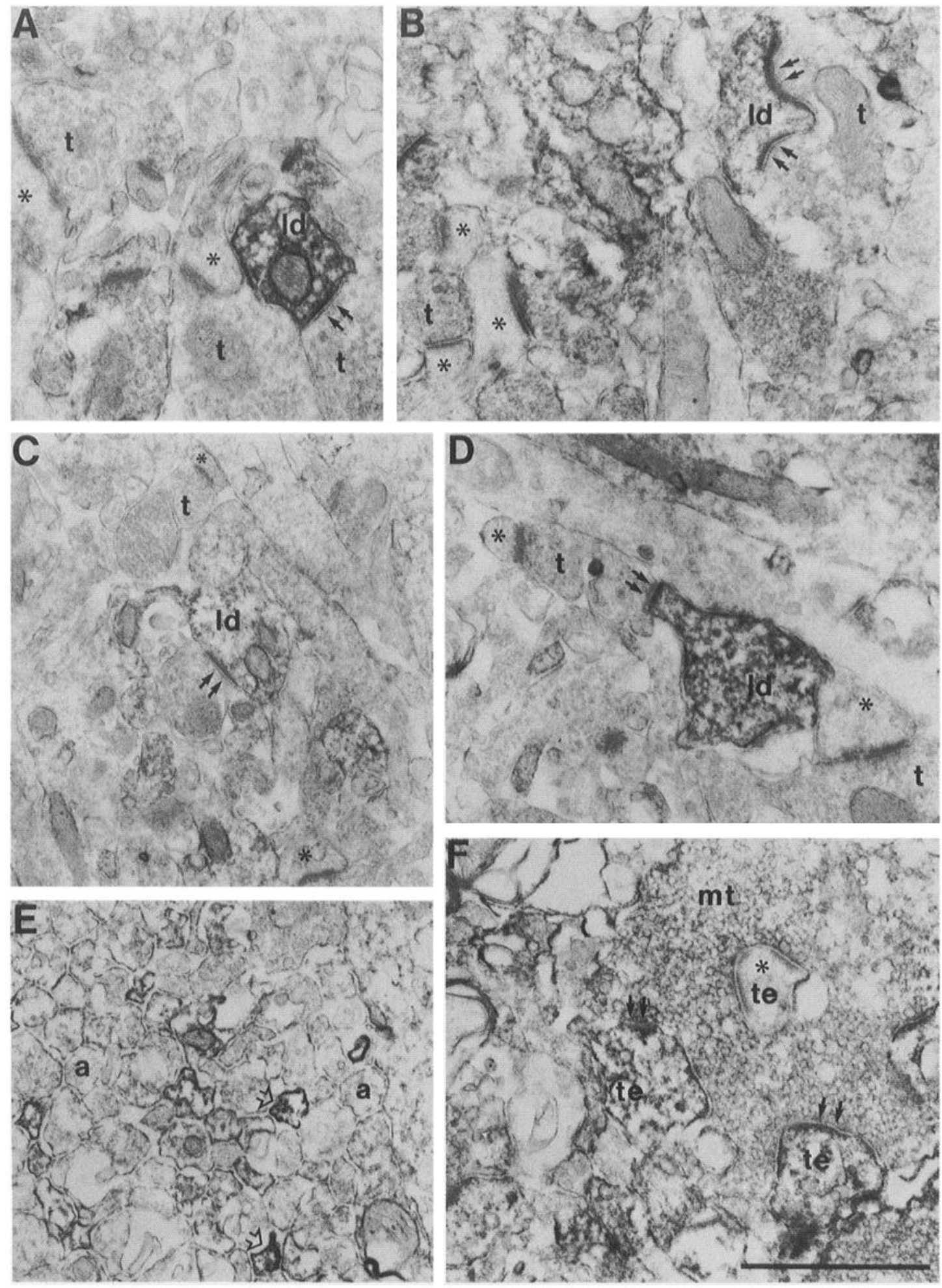

Figure 8. Ultrastructural localization of GluR2(4) immunoreactivity in the adult monkey hippocampus. $A$ and $B$, Examples of GluR2(4)-ir postsynaptic densities in CA1 on a labeled dendritic shaft $(A)$ and spine $(B)$. $C$ and $D$, Within the dentate molecular layer, immunolabeled postsynaptic densities were present on both labeled dendritic shafts $(C)$ and spines $(D) . E$ and $F$, Immunoreactivity within the stratum lucidum of $C A 3$ was found in both axonal $(E)$ and dendritic $(F)$ profiles. Mossy fiber terminals in CA3 often contained examples of immunolabeled and unlabeled thorny excrescences. $a$, axon; $l d$, labeled dendrite; $l s$, labeled spine; $m t$, mossy fiber terminal; $t$, terminal; te, thorny excrescence. Arrows, Labeled postsynaptic density; arrowheads, labeled mossy fiber axons; asterisk, unlabeled dendritic profile. Scale bar: $A, B, D$, and $E, 1.0 \mu \mathrm{m} ; C, 1.5 \mu \mathrm{m}$. 
fiber terminal often consisted of both labeled and unlabeled profiles (Fig. $8 F$ ). Myelinated axonal profiles were generally not immunoreactive throughout all regions of the hippocampus. However, a small subset of mossy fiber axons within the stratum lucidum were GluR2(4)-ir (Fig. $8 E$ ). Immunoreactivity within such unmyelinated axonal profiles was seen as labeled puncta in the axonal cytoplasm and often more intensely along membranes (Fig. 8E).

\section{Discussion}

The present study describes patterns of cellular colocalization between subunits of the AMPA/kainate, kainate, and NMDA receptor fanilies, as well as regional, cellular, and ultrastructural immunocytochemical patterns for the ionotropic GluR subunits GluR2(4) in the monkey hippocampus.

\section{Specificity of $m A B \quad 3 A 11$}

The mAb 3A11 has been shown to be specific for solely GluR2 in biochemical preparations including both RIA (present report) and western blots (Puchalski ct al., 1994) (corroborated by Sicgel et al., unpublished observation), while it interacts with both GluR2 and GluR4 in immunohistochemical labeling (present report) and immunoprecipitations (Puchalski et al., 1994) of transiently transfected HEK 293 cells. Sequence comparisons between the N-terminal region of GluR2 (against which the mAb was generated), and homologous regions of GluR1, GluR3, and GluR4, indicate that there is no obvious sequence of anino acid residues that would account for an epitope which is shared by GluR2 and GluR4, but is lacking in GluR1 and GluR3. It is therefore possible that $\mathrm{mAb} 3 \mathrm{~A} 11$ recognizes a linear sequence in GluR2, while its interaction with GluR4 requires a specific secondary or tertiary conformation. Thus, mAb $3 \mathrm{~A} 11$ is likely to label both subunits GluR2 and GluR4 in fixed monkey brain tissue sections and only GluR2 in denaturing biochemical preparations.

\section{Comparison with ligand binding and in situ hybridization data}

Ligand binding studies have shown that AMPA binding in rats is high in CA1 and dentate gyrus relative to CA3 (Insel et al., 1990). While AMPA binding reflects the composition and distribution of native heteromeric channels rather than individual subunits, the immunohistochemical distribution of GluR2(4) in the present study is consistent with the reported binding data. Studies using in situ hybridization histochemistry in rat hippocampus have shown GluR1-3 RNAs are highly expressed in hippocampus relative to other cortical structures (PellegriniGiampietro et al., 1991), while GluR4 RNA levels are relatively low (Keinänen et al., 1990). Similarly, Western blot and immunohistochemical analyses of various regions of rat and monkey brain suggest that GluR4 is found only at extremely low levels in the hippocampus relative to cerebellum and striatum (Martin et al., 1993, 1993). Taken together, these studies suggest that the pattern of immunoreactivity seen with the mAb $3 \mathrm{~A} 11$ in the monkey hippocampus reflect primarily the distribution of GluR2 rather than GluR4. However, preliminary data generated in monkey using a commercially available polyclonal antiGluR4 antibody (Chemicon, Temecula, CA) have resulted in labeling suggesting that the GluR4 subunit contributes to the pattern observed with mAb $3 \mathrm{~A} 11$.

\section{Colocalization of EAA receptor subunits}

The present data indicate that virtually all of the GluR5-7-ir neurons in the monkey hippocampus are also immunoreactive for both GluR2(4) and NMDAR1. Similarly, a high degree of colocalization between GluR1-3, GluR5-7, and NMDAR1 in monkey neocortex has been previously reported (Vickers et al., 1993; Huntley et al., 1994). These studies are consistent with physiological studies which have shown that individual neurons exhibit response properties typical of both NMDA and nonNMDA receptors within the hippocampus (MacDermott and Dale, 1987; Bekkers and Stevens, 1989).

Recent reports indicate that receptor subunits of the AMPA/ kainate, kainate, and NMDA receptor classes only combine to form functional channels with members of their own class (Brose et al., 1994; Puchalski et al., 1994). Therefore, the high degree of colocalization for GluR2(4) and GluR5-7, as well as GluR5-7 and NMDAR1 described within the present study is likely to reflect the presence of distinct AMPA/kainate, kainate, and NMDA receptors in virtually all hippocampal projection neurons. Additionally, confocal laser scanning microscopy has shown the colocalization of immunoreactivity for high affinity kainate receptor subunits with AMPA/kainate, as well as NMDA receptor subunits within individual spines (present study). Since it is generally believed that the majority of dendritic spines receive a single excitatory input (Peters and Jones, 1984; Peters et al., 1991), it is likely that various classes of EAA receptors can coexist at single synapses. This is consistent with physiologic observations that NMDA and non-NMDA receptors are present at individual excitatory synapses in rat hippocampus (Bekkers and Stevens, 1989).

Conversely, several recent ultrastructural studies have interpreted the presence of cytoplasmic immunoreactivity for various EAA receptor subunits and classes as representing cytoplasmic pools of receptors (Petralia and Wenthold, 1992; IIuntley et al., 1993; Martin et al., 1993; Huntley et al., 1994; Siegel et al., 1994). Manipulating the insertion of receptor subtypes from such pools within single dendritic spines would allow a neuron a great capacity for dynamic regulation of receptor composition and properties within a local environment. However, double-label immunogold electron microscopic studies will ultimately be necessary to determine the precise synaptic distribution of the different EAA receptor classes.

\section{Ultrastructural localization of GluR2(4)}

While light microscopic analyses indicate that all three classes of receptor subunits are colocalized at regional and cellular levels, ultrastructural data indicate that their subcellular distribution is not equivalent (Fig. 9). For example, GluR2(4) (present report) and GluR5-7 (Good et al., 1993) are localized to postsynaptic densities on thorny excrescences within the stratum lucidum of CA3, while NMDAR1 has been shown to be virtually absent from such dendritic specializations (Siegel et al., 1994). Conversely, all three receptor subtypes have been shown to be localized to postsynaptic densities on distal dendritic segments within the strata radiatum and moleculare (Good et al., 1993; Siegel et al., 1994) (present study). Such a subcellular distribution of NMDA and non-NMDA receptor subunits on CA3 pyramidal cells is consistent with previously demonstrated physiological data indicating that the excitatory mossy fiber input to CA 3 is almost exclusively mediated by non-NMDA receptors, while the associational/commissural input to the stratum radiatum is mediated by both NMDA and non-NMDA receptors (Cotman et al., 1986; Zalutsky and Nicoll, 1990; Katsuki et al., 1991) (Fig. 9).

There are several issues which influence the interpretation of 
Figure 9. Schematic representation of CA3 pyramidal cells with ultrastructural localization of EAA receptor subunits, laminar organization of afferent fibers (Frotscher et al., 1988), and forms of LTP exhibited (modified from Siegel et al., 1994). References regarding ultrastructural data of the EAA receptor subunits are; GluR2(4) (present study), NMDAR1 (Siegel et al., 1994), and GluR5-7 (Good et al., 1993). It remains unclear whether or not mossy fibers are immunoreactive for GluR5-7. See Cotman et al., 1986; Zalutsky and Nicoll, 1990; Katsuki et al., 1991, regarding forms of LTP demonstrated in CA3 and physiologic evidence for presynaptic NMDA receptors in stratum lucidum. $A / C$, associational/commissural fibers; $M F$, mossy fibers; $S L$, stratum lucidum; $S M$, stratum moleculare; $S O$, stratum oriens; $S P$, stratum pyramidale; $S R$, stratum radiatum.

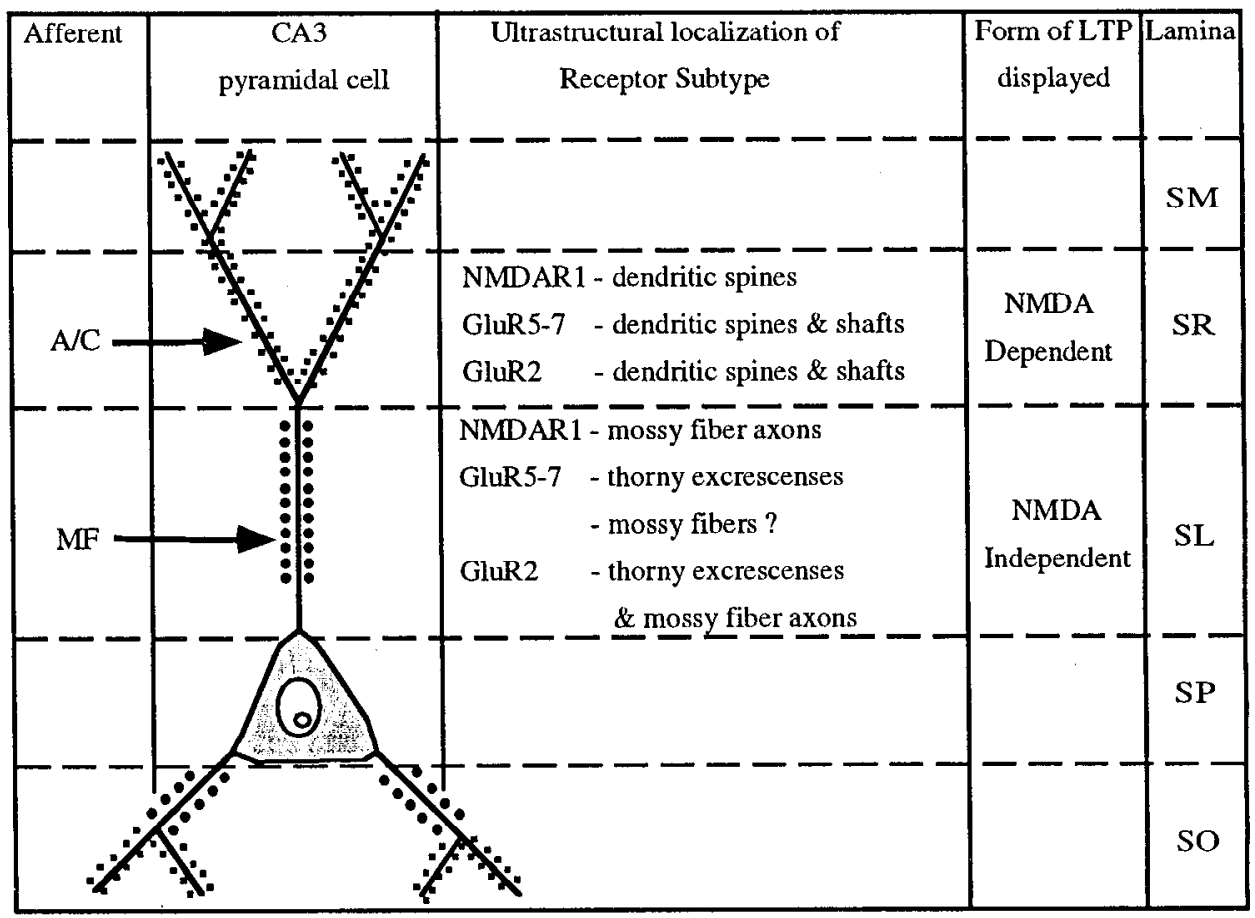

EAA receptor subunit immunoreactivity, and may contribute to apparent discrepancies between light and electron microscopic observations for a single antibody, as well as variations in labeling between different antibodies. For example, while NMDAR1 subunits are visualized at the light level within proximal apical dendrites of CA3 pyramidal cells in the stratum lucidum, previous reports have demonstrated that these subunits are not inserted into postsynaptic specializations within the characteristic complex dendritic spines termed thorny excrescences which arise from these dendrites (Siegel et al., 1994). Such intradendritic labeling has been attributed to the presence of both cytoplasmic pools of receptors and intracellular transport of receptors to their eventual destination in the distal dendritic spines (Huntley et al., 1993, 1993, 1994; Siegel et al., 1994). Additionally, 5-10\% of the axons within the mossy fiber projection display ultrastructural immunoreactivity for NMDAR1 (Siegel et al., 1994) and/or GluR2(4) (present study). This relatively small proportion of immunolabeled axons at the ultrastructural level results in a pattern of immunoreactivity at the light microscopic level in which the mossy fiber projection appears unlabeled or faintly labeled, as in Figures 5 and 6 . While it remains unclear as to whether or not mossy fiber axons are immunoreactive for GluR5-7 (Good et al., 1993), the relatively small proportion of axons which are immunoreactive for each of the other groups of subunits discussed above may contribute to interobserver differences in interpretation and a resulting difficulty in determining the degree to which all three classes are present in a small subset of mossy fiber axons. Finally, it has been previously reported that NMDAR 1-ir postsynaptic densities in hippocampus appear to be localized primarily to dendritic spines (Siegel et al., 1994). However, GluR2(4) (present report) and GluR5-7 (Good et al., 1993) are localized to postsynaptic densities on both dendritic spines and shafts. While interpretation of the observed labeling on dendritic shaft postsynaptic densities is complicated by the possibility that immunoreactive DAB product may spread beyond locations of specific antibody binding, differences between the immunoreactive patterns exhibited by antibodies directed against NMDAR1 (Siegel et al., 1994) and GluR2(4) (present report) suggest that this immunocytochemical method can reveal the apparent ultrastructural segregation of GluR subtypes.

\section{Differential vulnerability of hippocampal neurons}

Neurons within each subdivision of the hippocampus exhibit characteristic patterns of differential vulnerability to a host of deleterious processes. For example, portions of the hippocampal formation are major loci of damage in ischemia, kainate toxicity and epileptic seizure. Cellular pathology in ischemic injury is particularly severe in the CAl region, and can be dramatically decreased by specific NMDA antagonists (Rothman and Olney, 1987). Conversely, CA3 cells are among the most vulnerable to seizure-induced cellular pathologic changes (Choi, 1988) and kainate mediated damage (Nadler et al., 1981), but are relatively resistant to damage resulting from ischemic insult. Although such patterns may be influenced by the types of EAA receptors which mediate excitatory neurotransmission within specific intrinsic and extrinsic hippocampal circuits, the ubiquitous cellular patterns demonstrated within the present study for members of the AMPA/kainate, kainate, and NMDA reccptor familics suggest that the mere presence of a particular EAA receptor subunit or subtype within a particular neuronal class is insufficient to explain patterns of differential vulnerability.

\section{Summary and conclusions}

There are several implications of these data regarding glutamatergic transmission in the primate hippocampus. First, the AMPA/kainate subunits (GluR1-4) are well represented throughout the hippocampus and are likely to participate in all major hippocampal excitatory circuits. Double labeling studies demonstrate that kainate and NMDA receptors are also well represented throughout the hippocampus on a cellular level. Second, AMPA/kainate, kainate and NMDA receptors are broadly colocalized in hippocampal neurons, and at least in the case of $\mathrm{CA} 1$, are colocalized at individual spines. Third, these data taken 
together with previous studies demonstrate a segregation of GluRs in CA3 such that mossy fiber synapses are subserved in part by AMPA/kainate and kainate receptors (Good et al., 1993) (prcsent study) but not NMDA rcceptors (Siegel et al., 1994), while associational commissural inputs to the distal portion of CA3 pyramidal cell dendrites are subserved by all three families of GluRs. Thus, colocalization within a neuron can not necessarily be extended to the synaptic level. It is likely that such a relationship between identifiable circuits and a particular GluR profile is present in other hippocampal and neocortical circuits as well, but will be more difficult to observe in regions with less dramatic segregation of afferents. As complex, convergent, excitatory circuits are visualized in combination with subunit specific antibodies, it will be possible to link precise circuit elements to identified GluR subunits, and define more precisely the postsynaptic signature of excitatory circuits.

\section{References}

Bekkers JM, Stevens CF (1989) NMDA and non-NMDA receptors are co-localized at individual excitatory synapses in cultured rat hippocampus. Nature 341:230-233.

Boulter J, Hollman M, O'Shea-Greenfield A, Hartley M, Deneris E, Maron C, Heinemann S (1990) Molecular cloning and functional expression of glutamate receptor subunit genes. Science 249:10331037.

Brose N, Gasic GP, Rogers S, Moran T, Morrison JH, Jahn R, Heinemann SF (1994) Immunoaffinity purification of glutamate receptors of the non NMD $\Lambda$ and NMD $\Lambda$ type. J Biol Chem 269:16780-16784.

Choi DW (1988) Glutamate neurotoxicity and diseases of the nervous system. Neuron 1:623-634.

Colman CW, Flatman JA, Ganong AH, Perkins MN (1986) Effects of excitatory amino acid antagonists on evoked and spontaneous excitatory potentials in guinea-pig hippocampus. J Physiol (Lond) 378: 403-415.

Dieckmann CL, Tzagoloff A (1985) Assembly of the mitochondrial membrane system. J Biol Chem 260:1513-1520.

Frotscher M, Kugler P, Misgeld U, Zilles K (1988) Neurotransmission in the hippocampus. Adv Anat Embryol Cell Biol 111:1-103.

Good PF, Huntley GW, Rogers SW, Heinemann SH, Morrison JH (1993a) The distribution of kainate receptor subunits GluR5/6/7 in primate hippocampus. Brain Res 624:347-353.

Good PF, Rogers SW, Hcincmann SH, Morrison JH (1993b) Ultrastructural localization of kainate class glutamate receptor subunits GluR5/ 6/7 in monkey hippocampus and entorhinal cortex. Soc Neurosci Abstract 19:473.

Huntley GW, Rogers SW, Heinemann SH, Moran T, Janssen W, Archin N, Vickers JC, Morrison JH (1993a) Selective distribution of kainate receptor subunit immunoreactivity in monkey neocortex revealed by a monoclonal antibody against glutamate receptor subunits GluR5/6. J Neurosci 13:2965-2981.

Huntley GW, Vickers JC, Brose N, Janssen W, Archin N, Gasic GP, Jahn R, Heinemann SH, Morrison JH (1993b) NMDA receptors in monkey cerebral cortex: distribution of NMD $\Lambda$ R 1 subunit mRN $\Lambda s$ and organization and synaptic localization NMDAR1 subunit proteins. Soc Neurosci Abstr 19:472.

Huntley GW, Vickers JC, Janssen W, Brose N, Heinemann SH, Morrison JH (1994) Distribution and synaptic localization of immunocytochemically identified NMDA receptor subunit proteins in sensorymotor and visual cortices of monkey and human. J Neurosci 14: 3603-3619.

Insel TR, Miller LP, Gelhard RE (1990) The ontogeny of excitatory amino acid receptors in rat forebrain. I. $N$-methyl-D-aspartate and quisqualate receptors. Neuroscience 35:31-43.

Jahn R, Schiebler W, Ouimet C, Greengard P (1985) A 38,000-dalton membrane protein (p38) present in synaptic vesicles. Proc Natl Acad Sci USA 82:4137-4141.

Katsuki H, Kaneko S, Tajima A, Satoh M (1991) Separate mechanisms of long-term potentiation in two input systems to CA3 pyramidal neurons of rat hippocampal slices as revealed by the whole-cell patch-clamp technique. Neurosci Res 12:393-402.

Keinänen K, Wisden W, Sommer B, Werner P, Herb A, Verdoorn TA, Sackmann B, Seeburg PH (1990) A family of AMPA-selective glutamate receptors. Science 249:556-560.

Köhler G, Milstein C (1975) Continuous cultures of fused cells secreting antibody of predefined specificity. Nature 256:495-497.

Lowry O, Rosenbrough N, Farr A, Randall R (1951) Protein measurement with folin phenol reagent. J Biol Chem 193:265-275.

MacDermott AB, Dale N (1987) Receptors, ion channels and synaptic potentials underlying the integrative actions of excitatory amino acids. Trends Neurosci 10:280-284.

Martin LJ, Blackstone CD, Levey AI, Huganir RL, Price DL (1993a) AMPA receptor subunits are differentially distributed in rat brains. Neuruscience 53:327-358.

Martin LJ, Blackstone CD, Levey AI, Huganir RL, Price DL (1993b) The striatal mosaic in primates: striosomes and matrix are differentially enriched in ionotropic glutamate receptor subunits. J Neurosci 13:782-792.

Moriyoshi K, Masu M, Ishii T, Shigemoto R, Mizuno N, Nakanishi S (1991) Molecular cloning and characterization of the rat NMDA receptor. Nature 354:31-37.

Nadler JV, Evenson DA, Cuthbertson GJ (1981) Comparative toxicity of kainic acid and other acidic amino acids toward rat hippocampal neurons. Neuroscience 6:2505-2517.

Pellegrini-Giampietro DE, Bennett MVL, Zukin RS (1991) Differential expression of three glutamate receptor genes in developing rat brain: an in situ hybridization study. Proc Natl Acad Sci USA 88:41574161.

Peters A, Jones EG (1984) Classification of cortical neurons. In: Cerebral cortex, Vol 1, Cellular components of cerebral cortex (Peters A, Jones EG, eds), pp 107-121. New York: Plenum.

Petralia RS, Wenthold RJ (1992) Light and electron immunocytochemical localization of AMPA-selective glutamate receptors in the rat brain. J Comp Neurol 318:329-354.

Puchalski RB, Louis J-C, Brose N, Traynelis SF, Egebjerg J, Kukekov V, Wenthold RJ, Rogers SW, Lin F, Moran T, Morrison JH, Heinemann SF (1994) Selective RNA editing and subunit assembly of native glutamate receptors. Neuron 13:131-147.

Rogers SW, Hughes TE, Hollmann M, Gasic GP, Deneris ES, Heinemann $S$ (1991) The characterization and localization of the glutamate receptor subunit GluR1 in the rat brain. J Neurosci 11:27132724.

Rothman SM, Olney JW (1987) Excitotoxicity and the NMDA receptor. Trends Neurosci 10:299-302.

Seress L, Gulyas AI, Freund TF (1991) Parvalbumin- and calbindin D28k-immunoreactive neurons in the hippocampal formation of the macaque monkey. J Comp Neurol 313:162-177.

Siegel SJ, Brose N, Janssen WG, Gasic GP, Jahn R, Heinemann SF, Morrison JH (1994) Regional, cellular, and ultrastructural distribution of the glutamate receptor subunit NMDAR1 in monkey hippocampus. Proc Natl Acad Sci USA 91:564-568.

Vickers JC, Huntley GW, Edwards AM, Moran T, Rogers SW, Heinemann SH, Morrison JH (1993) Quantitative localization of AMPA/ kainate and kainate glutamate receptor subunit immunoreactivity in neurochemically identified subpopulations of neurons in the prefrontal cortex of the macaque monkey. J Neurosci 13:2982-2992.

Zalutsky RA, Nicoll RA (1990) Comparison of two forms of long-term potentiation in single hippocampal neurons. Science 248:1619-1624 [published erratum: Science 251:856, 1991]. 